\title{
Performance Evaluation of the Afinion AS100 Analyzer for Its Use in the Albumin Creatinine Ratio Test
}

\author{
Yong-Wha Lee and \\ Jeong Gwon Kim \\ Department of Laboratory \\ Medicine and Genetics, \\ Soonchunhyang University \\ Bucheon Hospital, \\ Soonchunhyang University \\ College of Medicine, \\ Bucheon, Korea
}

\begin{abstract}
Background: Early detection of moderately increased albuminuria using the albumincreatinine ratio (ACR) test is very important for preventing renal insufficiency and cardiovascular disease in patients with diabetes. The purpose of this study was to analyse the clinical usefulness of the Afinion AS100 Analyzer (Alere Technologies AS, Norway) for determining the ACR by evaluating its precision and linearity and comparing it with another conventional device.

Methods: Urine samples of patients and quality control materials were used for evaluation. The Afinion AS100 was used to measure albumin and creatinine, and the ACR was automatically calculated. The Cobas Integra 800 (Roche Diagnostics, Germany) was used as a reference instrument for correlation analysis. In accordance with the Clinical and Laboratory Standards Institute guidelines, precision, linearity, and turnaround time were evaluated, and the Afinion AS100 was compared with another device.

Results: The total coefficients of variation of albumin and creatinine were $2.8 \%$ and $2.9 \%$ for high concentration and $2.9 \%$ and $2.5 \%$ for low concentration, respectively. Both albumin and creatinine showed coefficients of determination of 0.999 or higher in linearity. Correlation coefficients of albumin, creatinine, and ACR were higher than the Clinical and Laboratory Standards Institute recommended value of 0.975 , suggesting a high correlation as well as showing significant correlation with a 24-hour urinary albumin level obtained using the Cobas Integra 800. Mean turnaround time was 5 minute 35 seconds.

Conclusions: The albumin, creatinine, and ACR tests performed with the Afinion AS100 showed satisfactory performance in terms of precision and linearity and showed good correlation with the central laboratory instrument and a 24-hour urine albumin quantitative test using a conventional instrument.
\end{abstract}

(J Lab Med Qual Assur 2017;39:147-153)

Key Words: Albumin-creatinine ratio, Moderately increased albuminuria, Afinion AS100

Received July 5, 2017, Revision received September 18, 2017, Accepted October 10, 2017

\section{서론}

당뇨 환자에서 중등도 알부민뇨는 당뇨의 주요 합병증 중 하 나인 당뇨성 신증의 예측인자이면서 심혈관질환의 독립적 위 험인자로 알려져 있다[1-3]. 선별검사를 통한 중등도 알부민 뇨의 조기 발견은 당뇨 환자에서 신부전 및 심혈관계 질환을 예방하는 데 있어서 매우 중요하다[4].

중등도 알부민뇨 검출을 위해 참고방법인 24시간 소변 채
집이 요구되나 환자가 직접 채뇨하여 수집함에 있어 매우 번 거롭고 불완전한 수집으로 인해 검사가 지연되거나 결과에 부 정확한 영향을 미칠 수 있게 된다[5]. 근래에는 24시간 소변 검사의 제한점을 극복하고 이를 보완하고 대체하기 위한 검사 로 무작위 소변을 이용한 알부민-크레아티닌 비율(albumincreatinine ratio, ACR) 검사가 많이 이용되고 있다. ACR검 사는 무작위 소변을 이용하여 중앙검사실의 자동화 분석장비 를 이용하여 알부민과 크레아티닌을 측정하고 두 항목의 비율 


\section{Journal of LABORATORY MEDICINE and QUALITY ASSURANCE}

\section{Yong-Wha Lee et al • Afinion AS100 for Albumin Creatinine Ratio}

을 계산하여 보고하게 된다. 소변 검체의 특성상 검체의 질을 보장하고 신속선별검사로서의 임상적 의미를 갖기 위해 채뇨 후 가급적 빠른 시간 내에 검사가 이루어져야 한다.

최근 현장검사로 사용될 수 있는 ACR검사기기인 Afinion AS100 (Alere Technologies AS, Oslo, Norway) 기기가 국내 에 소개되었다. 본 기기는 무작위 소변을 이용하여 면역반응원 리와 효소방법을 통해 즉시 알부민과 크레아티닌 정량결과를 산출해내는 측정기기로 중등도 알부민뇨의 신속선별이 가능 한 것으로 알려져 있다[6]. 그러나 본 측정법을 이용한 ACR검 사에 대해 중앙검사실의 자동화 장비와의 상관성 비교 등 전반 적인 분석 성능평가나 참고방법인 24시간 소변에서의 정량검 사와의 비교 등에 대한 평가가 국내에서 이루어진 바 없다.

본 연구에서는 Clinical and Laboratory Standards Institute (CLSI)에 제시된 평가지침에 따라 Afinion AS100 의 $\mathrm{ACR}$ 검사에 대한 정밀도, 직선성 등의 측정 성능평가 및 중 앙자동화 검사와 24 시간 뇨의 정량검사 등 기존 방법과의 상 관성 평가를 통해 임상적 유용성을 분석하고자 하였다.

\section{재료 및 방법}

\section{1. 재료}

1) 측정기기

Afinion AS100을 이용하여 알부민과 크레아티닌을 측정하 고 자동으로 $\mathrm{ACR}$ 이 산출되도록 하였다. $3.5 \mu \mathrm{L}$ 의 검체를 반 응시약이 내장된 카트리지 반응부에 분주하고 카트리지를 기 기에 장착한 후 검사가 이루어지도록 하였다. 알부민은 샌드위 치 결합단백 측정법(sandwich binding protein assay)을 통 해 내장된 디지털 카메라로 색깔을 측정하여 정량하였다. 크레 아티닌은 효소비색법(enzymatic colorimetric)을 이용해 530 $\mathrm{nm}$ 파장에서 발광 다이오드를 이용하여 측정하였다. 측정된 알부민, 크레아티닌과 ACR 결과값은 기기화면에 구현되도록 하였다.

알부민, 크레아티닌과 $\mathrm{ACR}$ 의 측정 가능범위는 각각 5.0$200.0 \mathrm{mg} / \mathrm{L}, 16.4-339.9 \mathrm{mg} / \mathrm{dL}$ 와 $1.0-1,225.0 \mathrm{mg} / \mathrm{g}$ 이다. 측 정 가능범위를 벗어난 것으로 나타난 검체는 10 배 희석하여 재측정하였고, 재측정 결과가 벗어난 경우 추가로 10 배 희석 하여 측정하였으며, 희석배수를 곱하여 결과값을 산출하였다.

상관성 분석을 위한 비교장비로 Cobas Integra 800 (Roche Diagnostics, Mannheim, Germany) 장비가 이용되었고, 본 기기의 알부민과 크레아티닌의 검사에는 각각 면역혼탁법과 Jaffe 방법이 적용되었다.
2) 검체

2017년 2월부터 5월까지 순천향대학교부천병원 진단검사의 학과로 요화학검사가 의뢰된 환자들의 소변 검체를 이용하였 는데, Cobas Integra 800을 통해 ACR이 0-8,000 mg/g에 분 포하는 검체를 선별하여 사용하였으며, 검체는 수집된 후 즉시 각각 분주하여 $-70^{\circ} \mathrm{C}$ 로 냉동시킨 후 검사 시 해동하여 사용 하였다. 정밀도 평가를 위한 검체로는 제조사로부터 제공된 내 부정도관리용 물질을 이용하였다. 본 연구는 순천향대학교부 천병원 기관생명윤리심의위원회의 승인(SCHBC NON2017004)을 받았다.

\section{2. 방법}

1) 정밀도

CLSI EP05-A3 지침에 따라 Afinion ACR 대조물질 level 1 (lot 10183354, Alere Technologies AS)과 level 2 (lot 10183355, Alere Technologies AS)를 이용하여 정밀도를 평 가하였다[7]. 알부민과 크레아티닌 검사에 대해 두 가지 농도 의 물질을 이용하여 5 일 동안 연속해서 하루 4회씩 측정하였 다. 하루 4회 검사는 오전 2회, 오후 2회 실시했으며, 오전과 오후 사이 검사간격은 2 시간 이상으로 하였다. 결과값에 대 해서는 검사 내 변이계수(within run coefficient of variation $[\mathrm{CV}])$, 검사일 간 변이계수(between day CV)와 총 변이계 수(total CV) 등을 계산하였다. 총 변이계수의 CV $(\%)$ 값은 Westgard QC (http://www.westgard.com)에 제시된 바람 직한 정밀도 수준과 비교하여 평가하였다.

\section{2) 직선성}

CLSI EP06-A에 준하여 평가하였다[8]. 알부민과 크레아티 닌 고농도의 환자 검체를 저농도의 환자 검체와 $4: 0,3: 1,2: 2$, $1: 3$ 와 $0: 4$ 의 비율로 단계적으로 혼합하여 5 가지 농도를 만든 후, 각각의 검체를 4회 반복 측정하여 구한 평균치로부터 회귀 직선식을 구하였다. 측정값이 직선식보다는 2 차 혹은 3 차 다 항회귀곡선에 가장 합당한 경우에는 최적의 다항회귀곡선을 구하였다.

\section{3) 상관성}

CLSI EP09-A3에 준하여 상관성을 평가하였다[9]. 비교장 비인 Cobas Integra 800을 통해 측정한 알부민, 크레아티닌과 $\mathrm{ACR}$ 결과를 기준으로 100 명의 환자로부터 채취된 100 개의 무작위 소변 검체와 100 개의 24 시간 소변 검체를 이용하여 평 가하였다. 무작위 소변 검체를 이용하여 Cobas Integra 800과 Afinion AS100에서 알부민, 크레아티닌과 ACR을 동시에 2회 


\section{Journal of LABORATORY MEDICINE and QUALITY ASSURANCE}

\section{Yong-Wha Lee et al • Afinion AS100 for Albumin Creatinine Ratio}

씩 측정하여 상관분석을 시행하였다. 또한 참고방법인 24시간 소변 알부민 총량과의 상관성을 평가하기 위해 Cobas Integra 800 을 이용하여 측정된 24 시간 소변 알부민 값을 24 시간 채뇨 량과 곱하여 얻어진 알부민 총량과 Afinion AS100에서 산출 된 $\mathrm{ACR}$ 값을 비교하였다.

\section{4) 검사 소요시간}

카트리지에 검체를 분주한 후 산출된 결과가 기기화면에 구현될 때까지 소요되는 시간을 검사 소요시간(turnaround time)으로 정하였고, 10 개의 검체에 대해 각 검체를 분주한 후 결과가 나올 때까지 소요되는 시간을 각각 측정한 후 평균 검 사 소요시간을 계산하였다..

\section{3. 통계}

각각의 평가에 대한 통계는 Analyse-it (Analyse-it Software Ltd., Leeds, UK)와 Microsoft Office Excel 2007 (Microsoft Co., Redmond, WA, USA) 프로그램을 이용하여 분석하였다.

\section{결과}

\section{1. 정밀도 평가}

알부민과 크레아티닌의 고농도물질의 검사 중 정밀도의 변 이계수는 각각 $2.6 \%$ 와 $1.7 \%$, 저농도물질은 $2.3 \%$ 와 $2.5 \%$ 였으며, 검사일 간 정밀도의 변이계수는 고농도물질은 각각 $1.0 \%$ 와 $2.3 \%$, 저농도물질은 $1.7 \%$ 와 $0.0 \%$ 였다. 알부민과 크
레아티닌의 총 변이계수는 고농도물질은 각각 $2.8 \%$ 와 $2.9 \%$, 저농도물질은 각각 $2.9 \%$ 와 $2.5 \%$ 였다(Table 1 ).

\section{2. 직선성 평가}

알부민과 크레아티닌 항목에 대한 직선성 평가에서 모두 결 정계수가 0.999 이상이며 기울기가 각각 1.007 과 0.999로 관 찰되었다(Table 2). 알부민은 직선식보다는 3차 다항회귀곡선 이 가장 적합하였고 크레아티닌은 직선식이 가장 합당하였다.

\section{3. 상관성 평가}

비교 방법과의 상관성 평가에서 알부민과 크레아티닌의 상 관계수는 각각 0.980 과 0.985 로 CLSI 권고치인 0.975 이상으 로 나타나 밀접한 상관관계를 갖는 것으로 나타났다(Figs. 1, 2). 알부민과 크레아티닌의 오차는 각각 $-5.8 \%$ ( $95 \%$ 신뢰구 간, $-9.4 \%$ to $-2.2 \%$ )와 $0.0 \%$ ( $95 \%$ 신뢰구간, $-2.0 \%$ to $2.0 \%$ )로 허용오차인 $10 \%$ 이내의 값을 보였다. $\mathrm{ACR}$ 의 상관 성 평가에서도 두 측정법 간에 유의한 상관관계를 보였고(기 울기, 0.90; y 절편, 7.54 ), 참고방법인 24시간 뇨 알부민 총량 과 $\mathrm{ACR}$ 과의 상관성 평가에서도 상관계수는 0.8373 으로 양 의 상관성의 판정기준인 0.7 이상이었으며 기울기 1.53 과 절 편 4.37의 $95 \%$ 신뢰구간은 각각 (1.22 to 1.70)과 ( -38.42 to 37.37)로 관찰되었다(Figs. 3, 4).

\section{4. 검사 소요시간}

10 개 검체의 총 검사 소요시간은 55 분 50 초로 측정되었고 한 개 검체에 대한 평균 검사 소요시간은 5 분 35 초로 계산되었다.

Table 1. Precision of albumin and creatinine measurements by the Afinion AS100

\begin{tabular}{|c|c|c|c|c|c|c|c|c|c|}
\hline \multirow{2}{*}{ Items (units) } & \multirow{2}{*}{ Level } & \multirow{2}{*}{ Mean } & \multicolumn{2}{|c|}{ Within run } & \multicolumn{2}{|c|}{ Between day } & \multicolumn{2}{|c|}{ Total } & \multirow{2}{*}{$\begin{array}{c}\text { Desirable } \\
\text { precision }(\%)^{x}\end{array}$} \\
\hline & & & SD & $\mathrm{CV}(\%)$ & $\mathrm{SD}$ & CV (\%) & SD & $\mathrm{CV}(\%)$ & \\
\hline \multirow[t]{2}{*}{ Albumin $(\mathrm{mg} / \mathrm{L})$} & High (lot 10183355) & 71.90 & 1.85 & 2.6 & 0.75 & 1.0 & 2.00 & 2.8 & 18.0 \\
\hline & Low (lot 10183354) & 11.33 & 0.26 & 2.3 & 0.19 & 1.7 & 0.32 & 2.9 & \\
\hline \multirow[t]{2}{*}{ Creatinine $(\mathrm{mg} / \mathrm{dL})$} & High (lot 10183355) & 211.97 & 3.69 & 1.7 & 4.93 & 2.3 & 6.15 & 2.9 & 18.2 \\
\hline & Low (lot 10183354) & 88.87 & 2.18 & 2.5 & 0.00 & 0.0 & 2.18 & 2.5 & \\
\hline
\end{tabular}

Abbreviations: SD, standard deviation; CV, coefficient of variation.

*Based on the Westgard QC, http://www.westgard.com/biodatabase1.htm.

Table 2. Linearity of albumin and creatinine measurements by the Afinion AS100

\begin{tabular}{llcccc}
\hline Items & Units & Linearity range & $\boldsymbol{R}^{2}$ & Best fit & Best nonlinear fit \\
\hline Albumin & $\mathrm{mg} / \mathrm{L}$ & $5.1-194.0$ & 0.9990 & - & 3rd order polynomial \\
Creatinine & $\mathrm{mg} / \mathrm{dL}$ & $16.5-303.0$ & 0.9999 & Linear fit & - \\
\hline
\end{tabular}

Abbreviation: $R^{2}$, coefficient of determinations. 


\section{Journal of LABORATORY MEDICINE and QUALITY ASSURANCE}

\section{Yong-Wha Lee et al • Afinion AS100 for Albumin Creatinine Ratio}
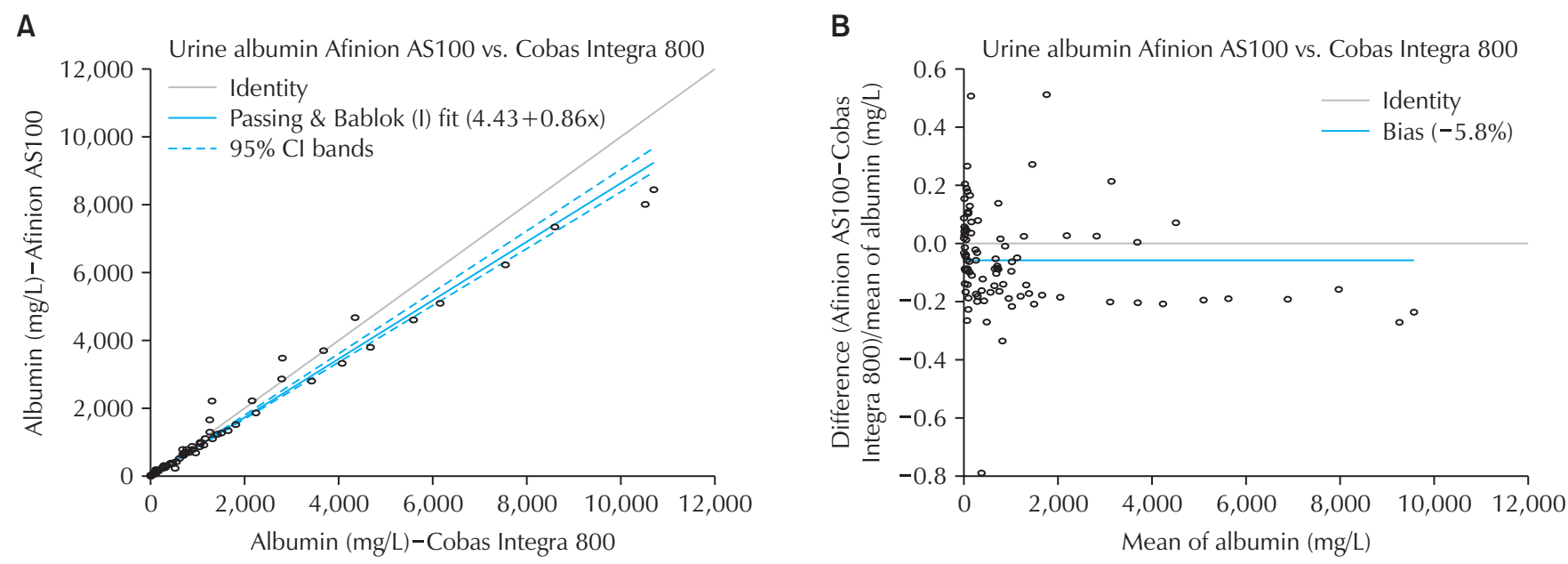

Fig. 1. Correlation of urine albumin quantitative results. (A) Scatter plot with Passing and Bablok plot. The blue line represents the linear regression and the grey line depicts a theoretical line with a slope of 1.0 and a y intercept of 0 . (B) Difference plot. The blue line represents the bias (average difference) and the grey line depicts a theoretical line with 0 bias between methods.

A

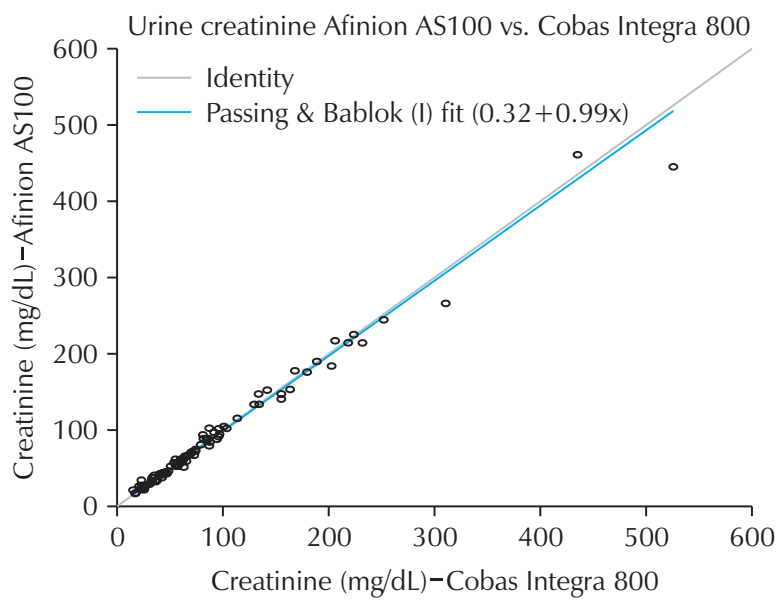

B

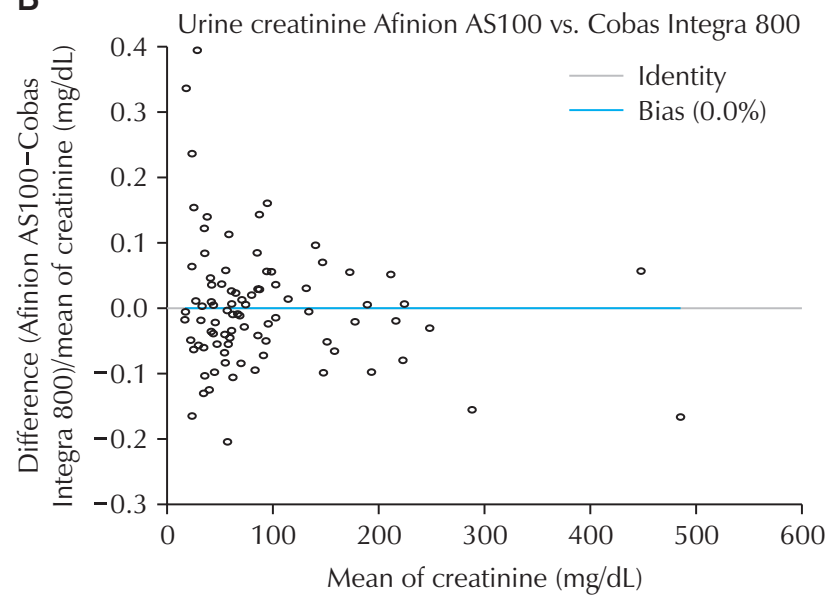

Fig. 2. Correlation of urine creatinine quantitative results. (A) Scatter plot with Passing and Bablok plot. The blue line represents the linear regression and the grey line depicts a theoretical line with a slope of 1.0 and a y intercept of 0 . (B) Difference plot. The blue line represents the bias (average difference) and the grey line depicts a theoretical line with 0 bias between methods.

고찰

Afinion AS100에 대한 평가를 통해 본 검사법은 참고방법 인 24시간 소변의 알부민 정량검사와 매우 높은 상관성을 보 였을 뿐만 아니라 검사 소요시간도 5 분 35 초로 매우 짧으므로 기존 24 시간 소변검사를 보완함으로써 진료현장에서 중등도 알부민뇨의 신속선별에 매우 유용할 것으로 보여졌다.

중등도 알부민뇨는 당뇨의 주요 합병증 중 하나인 당뇨성 신 증의 초기 단계의 표지자이면서 심혈관질환의 위험인자이므 로 이들을 조기에 선별할 수 있는 중요한 검사라고 할 수 있다
〔10]. 미국 당뇨협회에서는 소변의 알부민 배출을 측정하는 표 준방법으로 24 시간 소변을 채취하여 알부민을 정량 측정하는 것으로 제시하고 있다[11]. 그러나 근래 들어 24 시간 소변 채 취의 번거로움과 검체 안정성에 대한 문제로 인해 ACR검사가 중등도 알부민뇨의 표지자로서 임상현장에서 많이 이용되고 있고 최근에는 현장 검사기기 등을 이용하여 보다 간편하고 빠 르게 선별진단에 이용하려는 시도가 늘고 있다.

본원에서는 자동화 장비인 Cobas Integra 800을 이용하여 무작위 소변의 알부민과 크레아티닌을 측정하고 검사정보시 스템의 계산식을 이용하여 $\mathrm{ACR}$ 을 보고해 오고 있다. 기존에 
A

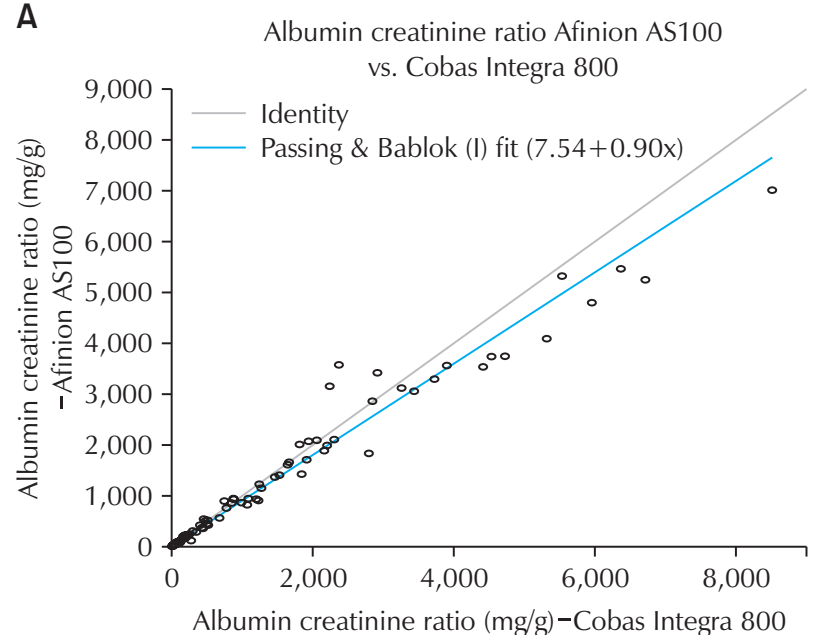

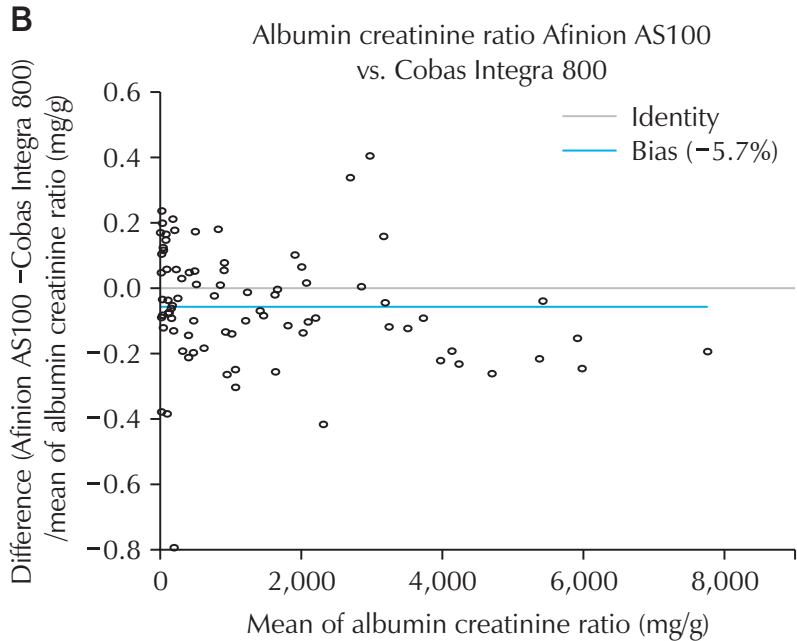

Fig. 3. Correlation of urine albumin-creatinine ratio. (1) Scatter plot with Passing and Bablok plot. The blue line represents the linear regression and the grey line depicts a theoretical line with a slope of 1.0 and a y intercept of 0 . (2) Difference plot. The blue line represents the bias (average difference) and the grey line depicts a theoretical line with 0 bias between methods.

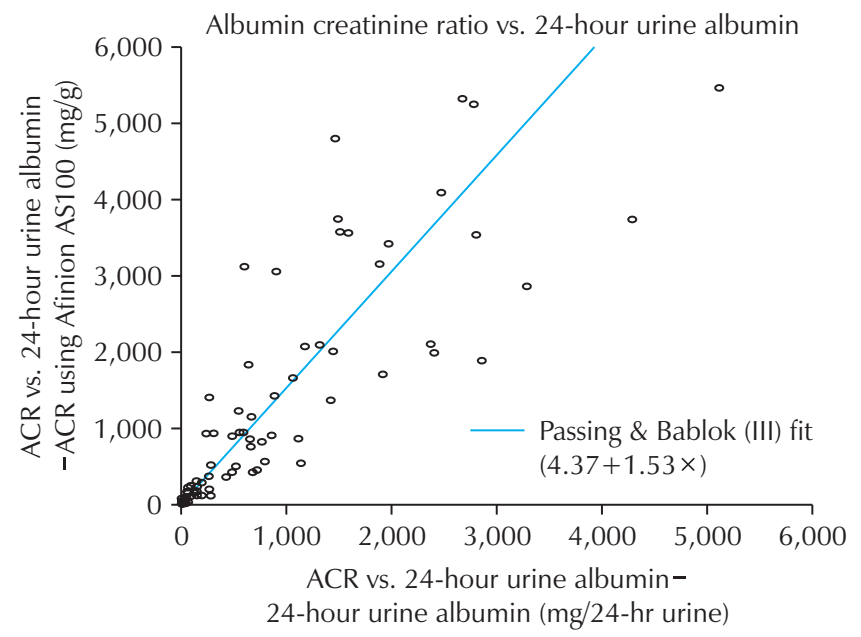

Fig. 4. Correlation between urine albumin-creatinine ratio using the Afinion AS100 and 24-hr urine albumin quantitation using the Cobas Integra 800. Scatter plot with Passing and Bablok plot. The blue line represents the linear regression.

는 채뇨 후 검체가 중앙검사실로 운반되고 접수된 후 알부민 과 크레아티닌이 각각 검사된 후 검사정보시스템을 통해 자동 계산된 $\mathrm{ACR}$ 이 보고되는 체계를 거치다 보니 검사에 30 분 이 상 소요되었으나 진료현장에서 즉시 검사가 진행되는 Afinion $\mathrm{AS} 100$ 은 검사 소요시간이 5 분 35 초로 매우 짧은 것으로 관찰 되었다.

정밀도 평가에서 저농도물질에 대한 알부민과 크레아티닌의 정밀도는 Westgard $\mathrm{QC}$ 에서 제시된 정밀도 수준인 $18.0 \%$ 와 $18.2 \%$ 과 비교하여 매우 우수한 것으로 나타났다. 요검사는 정
확한 결과를 위해 채취한 지 2시간 이내 혹은 마개를 막고 냉 장고에 보관된 지 수시간 이내의 소변 검체를 이용하여 검사가 시행되도록 하고 있는데, 2 개월까지 냉동 보관된 검체를 이용 한 평가에도 불구하고 저농도와 고농도의 검체 결과에서 모두 매우 우수한 정밀도 결과를 보였다.

직선성 평가에서는 두 항목 모두에서 모두 결정계수가 0.999 이상이며 기울기 0.999-1.007로 매우 우수한 직선성을 보여주었다. 알부민은 직선식보다는 3 차 다항회귀곡선이 가장 적합한 것으로 분석되었고, 비직선성 \%는 최저농도 검체에서 $-34.94 \%$ 로 나타났지만 최저농도가 $5.1 \mathrm{mg} / \mathrm{L}$ 인 점과 11.33 $\mathrm{mg} / \mathrm{L}$ 의 저농도에서 총 정밀도가 $2.9 \%$ 인 점, 이 외의 모든 농 도에서 $3.9 \%$ 이하의 비직선성 \%를 보인 점과, 1 차 식에 합당 한 직선성을 보이는 점에 미루어 매우 우수한 직선성을 갖는 것으로 평가되었다.

임상적으로 직선성을 초과하는 검체가 상당수 있고 희석 여 부에 따라 직선성 분석결과가 달라질 수 있으므로 이들에 대한 적절한 희석방침이 마련되어야 하고 향후 직선성 범위에 대한 재평가가 필요하다고 볼 수 있다.

상관성 평가에서 알부민, 크레아티닌과 ACR 모두 Cobas Integra 800과 매우 높은 상관성을 보였다. 알부민이 의학 적 결정농도인 $70 \mathrm{mg} / \mathrm{L}$ 를 넘는 높은 농도범위에서 Afinion AS100이 Cobas Integra 800에 비해 다소 낮은 결과치를 나타 내는 경향을 보였다. 하지만 알부민과 크레아티닌 각각 의학적 결정농도인 $70 \mathrm{mg} / \mathrm{L}$ 와 $200 \mathrm{mg} / \mathrm{dL}$ 를 포함한 임상적으로 의 미가 있는 농도범위인 0-10,000 mg/L와 0-500 mg/dL에서는 허용오차인 $10 \%$ 이내의 값을 보였고 CLSI 권고기준인 0.975 


\section{Journal of LABORATORY MEDICINE and QUALITY ASSURANCE}

Yong-Wha Lee et al • Afinion AS100 for Albumin Creatinine Ratio

이상의 상관계수를 만족하였다. 참고방법인 24 시간 소변의 알 부민 정량검사결과와의 상관성 분석에서도 두 검사가 단위 와 규격이 서로 다르므로 직접적인 비교는 불가능함에도 불 구하고 두 검사에서 측정된 결과 간에 상관계수 0.8373 의 양 의 상관성이 있는 것으로 관찰되었다. 본 결과를 통해 Afinion $\mathrm{AS} 100$ 을 이용한 ACR검사는 기존 24시간 소변의 알부민 정 량검사를 대체하거나 보완할 수 있을 것으로 생각되었고 이를 통해 24시간 소변 수집의 불편함과 번거로움을 최소화할 수 있을 것으로 생각되었다. 다만 측정 가능범위를 벗어나는 고농 도 검체일 경우 희석 전처리 및 재검사가 요구된다는 점은 현 장검사로 보완되어야 할 사항인 것으로 생각되었다. 결론적으 로, Afinion AS100으로 시행한 알부민, 크레아티닌과 ACR검 사는 정밀도와 직선성에 있어서 매우 만족할 만한 성능을 보였 고, 중앙검사실 기기 및 참고방법인 24시간 소변 알부민 정량 검사와도 좋은 상관성을 보여 기존의 24 시간 소변 알부민 정 량검사를 대체 또는 보완할 수 있을 것으로 생각되었다.

\section{감사의 글}

본 연구에 지원을 아끼지 않은 엘리어헬스케어(주)에 깊은 감 사를 드린다.

\section{REFERENCES}

1. Rowe DJ, Dawnay A, Watts GF. Microalbuminuria in diabetes mellitus: review and recommendations for the measurement of albumin in urine. Ann Clin Biochem 1990;27(Pt 4):297-312.

2. Janssen WM, Hillege H, Pinto-Sietsma SJ, Bak AA, De Zeeuw D, de Jong PE, et al. Prevention of renal and vascular end-stage disease: low levels of urinary albumin excretion are associated with cardiovascular risk factors in the general population. Clin Chem Lab Med 2000;38: 1107-10.

3. Nisell H, Trygg M, Back R. Urine albumin/creatinine ratio for the assessment of albuminuria in pregnancy hypertension. Acta Obstet Gynecol Scand 2006;85:132730.

4. Jain A, Rao N, Sharifi M, Bhatt N, Patel P, Nirmal D, et al. Evaluation of the point of care Afinion AS100 analyser in a community setting. Ann Clin Biochem 2017;54:331-41.

5. Waugh JJ, Bell SC, Kilby MD, Blackwell CN, Seed P, Shennan AH, et al. Optimal bedside urinalysis for the detection of proteinuria in hypertensive pregnancy: a study of diagnostic accuracy. BJOG 2005;112:412-7.

6. Omoruyi FO, Mustafa GM, Okorodudu AO, Petersen JR. Evaluation of the performance of urine albumin, creatinine and albumin-creatinine ratio assay on two POCT analyzers relative to a central laboratory method. Clin Chim Acta 2012;413:625-9.

7. Clinical and Laboratory Standards Institute. Evaluation of precision of quantitative measurement procedures: EP05-A3. 3rd ed. Wayne (PA): Clinical and Laboratory Standards Institute, 2014.

8. Clinical and Laboratory Standards Institute. Evaluation of the linearity of quantitative measurement procedures: a statistical approach: EP06-A. Wayne (PA): Clinical and Laboratory Standards Institute, 2003.

9. Clinical and Laboratory Standards Institute. Measurement procedure comparison and bias estimation using patient samples: EP09-A3. 3rd ed. Wayne (PA): Clinical and Laboratory Standards Institute, 2013.

10. Keane WF, Eknoyan G. Proteinuria, albuminuria, risk, assessment, detection, elimination (PARADE): a position paper of the National Kidney Foundation. Am J Kidney Dis 1999;33:1004-10.

11. American Diabetes Association. American Diabetes Association clinical practice recommendations 2001. Diabetes Care 2001;24 Suppl 1:S1-133. 


\section{Afinion AS100을 이용한 Albumin Creatinine Ratio 검사의 성능 평가 \\ 이용화 • 김정권 \\ 순천향대학교 의과대학 순천향대학교부천병원 진단검사의학과}

배경: 알부민-크레아티닌 비율(albumin creatinine ratio, ACR)검사를 이용한 중등도 알부민뇨의 조 기 발견은 당뇨 환자에서 신부전 및 심혈관계 질환을 예방하는 데 있어서 매우 중요하다. 국내에 소 개된 ACR 측정기기인 Afinion AS100 (Alere Technologies AS, Norway)에 대한 정밀도, 직선성과 참 고 표준방법과의 상관성 평가를 통해 임상적 유용성을 분석하고자 하였다.

방법: 요화학검사를 의뢰한 환자들의 소변 검체와 내부정도관리용 물질을 이용하여 평가하였다.

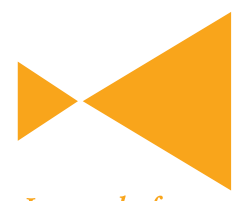

Journal of

LABORATORY MEDICINE

and

QUALITY ASSURANCE Afinion AS100을 이용하여 알부민과 크레아티닌을 측정하고 자동으로 ACRO 산출되도록 하였고, 상관성 분석을 위한 비교장비로 Cobas Integra 800 (Roche diagnostics, Germany) 장비를 이용하 였다. Clinical and Laboratory Standards Institute (CLSI) 지침에 따라 정밀도, 직선성, 상관성 및 검사 소요시간을 평가하였다.

결과: 알부민과 크레아티닌의 총 변이계수는 고농도물질은 각각 $2.8 \%$ 와 $2.9 \%$, 저농도물질은 각각 $2.9 \%$ 와 2.5\%였다. 알부민과 크레아티닌 모두 직선성 평가에서 결정계수가 0.999 이상으로 우수한 직선성을 보였다. 비교방법과의 상관성 평가에서 알부민, 크레아티닌과 ACR 모두 상관계수가 CLSI 권고치인 0.975 이상으로 나타나 밀접한 상관성을 보였고 참고방법인 24시간 뇨 알부민 총량과도 유의한 상관관계를 보였다. 평균 검사 소요시간은 5분 35초로 계산되었다.

결론: Afinion AS100으로 시행한 알부민, 크레아티닌과 ACR검사는 정밀도와 직선성에 있어서 매우 만족할 만한 성능을 보였고, 중앙검사실 기기 및 참고방법인 24시간 소변 알부민 정량검사와도 좋 은 상관성을 보였다.

(J Lab Med Qual Assur 2017;39:147-153)

교신저자: 이용화

우)14584 경기도 부천시 원미구 조마루로 170 , 순천향대학교 의과대학 순천향대학교부천병원 진단검사의학과 Tel: 032)621-5943, Fax: 032)621-5944, E-mail: lywmd@schmc.ac.kr 